\title{
Molecular Detection of Human Cytomegalovirus (HCMV) Among Infants with Congenital Anomalies in Khartoum State, Sudan
}

\author{
Maha G. Ebrahim ${ }^{1}$, Aisha S. Ali ${ }^{2}$, Mohamed O. Mustafa ${ }^{3}$, Dalal F. Musa ${ }^{4}$, Abdel Rahim M. El \\ Hussein $^{3}$, Isam M. Elkhidir ${ }^{5}$ and Khalid A. Enan ${ }^{3, *}$ \\ ${ }^{1}$ Department of Microbiology, Faculty of Medical Laboratory Sciences, Al Neelain University, Khartoum, Sudan \\ ${ }^{2}$ Department of Microbiology, Faculty of Medical Laboratory Sciences, National University, Sudan \\ ${ }^{3}$ Departmemt of Virology, Central Laboratory, Ministry of Science and Communication, Khartoum, Sudan \\ ${ }^{4}$ Department of Microbiology, Faculty of Medical Laboratory Sciences, Sudan University Science and Technology, \\ Sudan \\ ${ }_{5}^{5}$ Department of Microbiology and Parasitology, Faculty of Medicine, University of Khartoum, Khartoum, Sudan
}

\begin{abstract}
Human Cytomegalovirus (HCMV) infection still represents the most common potentially serious viral complication in humans and is a major cause of congenital anomalies in infants. This study is aimed to detect HCMV in infants with congenital anomalies.

Study subjects consisted of infants born with neural tube defect, hydrocephalus and microcephaly.

Fifty serum specimens ( 20 males, 30 females) were collected from different hospitals in Khartoum State. The sera were investigated for cytomegalovirus specific immunoglobin $\mathrm{M}$ ( $\mathrm{IgM})$ antibodies using enzyme-linked immunosorbent assay (ELISA), and for Cytomegalovirus DNA using polymerase chain reaction (PCR).

Out of the 50 sera tested, one patient's (2\%) sample showed HCMV IgM, but with no detectable DNA, other 4(8.2\%) sera were positive for HCMV DNA but with no detectable IgM.

Various diagnostic techniques should be considered to evaluate HCMV disease and routine screening for HCMV should be introduced for pregnant women in this setting. It is vital to initiate further research work with many samples from different area to assess prevalence and characterize HCMV and evaluate its maternal health implications.
\end{abstract}

Keywords: Congenital anomalies, ELISA, HCMV, PCR, Sudan.

\section{INTRODUCTION}

Human Cytomegalovirus (HCMV) belongs to the Herpesviridae family and is a common cause of infection among humans. The virus undergoes periods of activity and periods of latency and, once a person has been infected, the virus remains in the host's body indefinitely and can be reactivated due to many stress factors [1].

The virus is transmitted to fetuses via the transplacental route. The earlier the virus is transmitted to the fetus, the worst the prognosis and the greater the chance of severe malformations. The maternal infection can either be primary (in women who had never been infected before) or recurrent (by viral reactivation or reinfection by other viral strains) [2].

\footnotetext{
* Address correspondence to this author at the Department of Virology, Central Laboratory- Ministry of Science \& Communication, Sudan; Tel: +249-912651103; Fax: +249155183855-P.O.Box: 7099; E-mail: khalid.enan@gmail.com
}

Congenital HCMV is a neglected problem worldwide, both at the health care workers level and the general public level. This is being attributed to the fact that most of the infections are asymptomatic and may not be recognized at birth. Moreover sequelae of HCMV are sometimes delayed in onset with the result that retrospective diagnosis becomes more challenging.

Finally, the wrong perception that congenitally infected infants (babies) born to seropositive mothers usually have normal outcome has led to less attention to congenital HCMV in developing countries [3]. However, it is becoming clear that in developing countries with high seropositive populations a high rate of HCMV infection and higher rate of congenital hearing loss in developing countries do exist [3, 4].

Prevention and control of HCMV remains an ongoing challenge. The high diversity and infection with multiple differing strain of the virus represent a potential barrier to the development of effective vaccines $[5,6]$. 
Moreover, at the population level, there is certainly potential that vaccination of women with preexisting immunity might boost their immunity and reduce the incidence of congenital infection and/or disease in this population. Updated estimates of the produced congenital CMV and its impact are needed for increased awareness of congenital CMV infection and disease, allocation of public health resources, and determination of the cost-effectiveness of potential interventions [7,8]. The current study aims to collect preliminary information regarding this problem in Sudan and highlight its extent and to stimulate further research to in this field in the country.

\section{MATERIAL AND METHOD}

Study Site: This is a descriptive cross-sectional neonates study conducted for 50 newborn infants with suspected HCMV infection (complained from neural tube defect, hydrocephalus and microcephaly). The study was conducted in the neonate intensive care units (NICUs) of three Hospitals in Khartoum State (Ibrahim Malik teaching Hospital, Khartoum Teaching Hospital and Omdurman Maternity Hospital), during September 2014 to January 2015.

Samples Collection: Blood samples were collected from infants with various congenital anomalies $(n=50)$ after birth (age range was from one day to four months). Blood (2-5 $\mathrm{ml})$ was collected in plain containers and transported on wet ice to the laboratory for immediate processing. Sera were separated from blood samples by centrifugation and stored at -20 till tested.

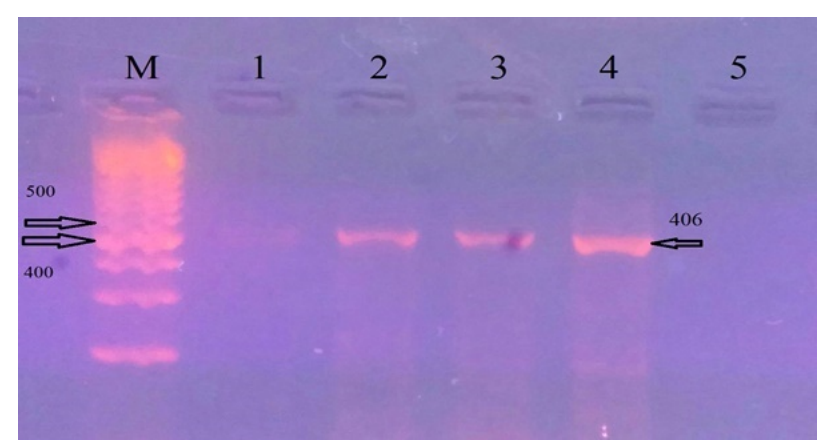

Fig. (1). HCMV PCR results (406 bp) on $2 \%$ agarose gel. Lanes 1-3 show positive patients Samples; Lane 4 shows positive control; Lane 5 shows negative control result of HCMV; M: 100 bp DNA size marker.

Capture ELISA IgM: Serum samples were tested for the presence of CMV $\operatorname{IgM}$ antibodies using $3^{\text {rd }}$ generation commercially available ELISA kits (GENESIS Diagnostic, Omega Diagnostic Group PLC, Cambridge Shine, UK), according to the manufacturer's instructions.
DNA Extraction: Serum samples were processed by using commercial DNA extraction kit (Bio Basic Inc One Tube Viral DNA Isolation Buffer), which was performed according to the manufacturer's instructions.

DNA Amplification: The outer prime sequences (Forward: 5-GGA TCC GCA TGG CAT TCA CGT ATG T-3, reverse: 5-GAA TTC AGT GGA TAA CCT GCG GCG A-3) were selected from a conserved region of the fourth exon of the HCMV immediate early (IE) gene, located in the Hind III-X fragment of the AD-169 strain $[9,10]$. Optimized PCR reaction for HCMV DNA amplification was performed according to [10] briefly, 3 ul of DNA extract was added to PCR premix (Maxime PCR premix kit (i-Tag)) containing i-Tag TM DNA polymerase, dNTP mixture and reaction buffer. Two ul of primers and $13 \mathrm{ul}$ of distilled water were then added to PCR premix. The PCR program consisted of $95^{\circ} \mathrm{C}$ for 10 min, followed by 35 cycles of $95^{\circ} \mathrm{C} 45 \mathrm{~s}, 58^{\circ} \mathrm{C} 50 \mathrm{~s}$ and $72^{\circ} \mathrm{C} 45 \mathrm{~s}$ with a final extension at $72^{\circ} \mathrm{C} 5 \mathrm{~min}$. The PCR was carried out in a total volume of $25 \mathrm{ul}$ and the amplified PCR product was detected by agarose gel electrophoresis. The product was visualized by staining with $0.15 \%$ Ethidium bromide using UV gel documentation system INGeNius. The expected size of immediate early (IE) gene amplicon was 406 bp (Fig. 1).

\section{Ethical Review}

The study was approved by the Ethical Review Committee (ERC) of the Ministry of Health Khartoum State, Sudan. Informed consents were obtained from parents or legal guardians of children.

\section{RESULTS}

A total of 50 newborn patients were enrolled in this study, $20(40 \%)$ of them were males and $30(60 \%)$ were females.

Table 1. cross- tabulation between PCR and ELISA (IgM) results for the diagnosis of $\mathrm{HCMV}$ in sera samples collected from neonates with congenital anomalies in Khartoum State, Sudan, during the period from September 2014 to January 2015.

\begin{tabular}{|c|c|c|c|c|}
\hline \multirow{2}{*}{ ELISA } & \multicolumn{2}{|c|}{ PCR } & \multirow{2}{*}{ Total } & \multirow{2}{*}{ Agreement } \\
\cline { 2 - 4 } & Positive & Negative & & \\
\hline IgM Positive & 1 & 0 & 1 & \multirow{2}{*}{$94 \%$} \\
\hline Negative & 3 & 46 & 49 & \\
\hline Total & 4 & 46 & 50 & \\
\hline
\end{tabular}

One male ( $2 \%)$ out of 50 neonates with microcephaly was found to be HCMV-IgM antibodies positive and 49 (98\%) were found to be HCMV IgM antibodies negative.

In addition, 4(8.2\%) samples were HCMV DNA 
positive. These samples were from 2 males and 2 female neonates all of them suffered from congenital neural tube defect and hydrocephalus). None of the microcephally patients were DNA positive. Fifty samples were used for comparison of both ELISA and PCR results, out of them, 4 samples were positive for PCR, one sample for both ELISA IgM and PCR and 46 samples were negative by both testes. This revealed an overall agreement of $94 \%$ $(47 / 50)$ between the two tests Table 1.

\section{DISCUSSION}

Congenital CMV infection is the most common congenital infection worldwide. The rate of infection varies in different population and different age groups. The maternal primary or reactivated infection during pregnancy can lead to Congenital CMV infection, but maternal reinfection with different strains of CMV can rarely lead to congenital symptomatic infection.

Although HCMV is a major public health problem throughout the world, only limited information is available about the incidence and the history of this infection in Sudan.

The aim of the present study was to determine prevalence using ELISA and PCR of HCMV among patient with congenital neural tube defect, hydrocephalus and microcephaly in Khartoum State. In the present study, HCMV IgM antibodies were found in $1(2 \%)$, and virus DNA was found in $4(8 \%)$ of the tested samples.

In Sudan, high seroprevalence of HCMV (IgM antibodies) among congenitally, infected neonates in Khartoum State $(94.3 \%)$ was recorded by Nahla et al. (2011). This is in sharp contrast with the findings of present study. The difference between the two studies may be due to different patient inclusion criteria in the two studies depending on the type of specimens that were available at time of collection, hence in our study the specimens were from patients with tube defects, hydrocephaly and microcephaly, while in the other study specimen were mainly from cases of respiratory infection, hydrocephaly and jaundice.

On the other hand, Khairi et al. (2013) found CMV IgM antibodies in $6 \%$ of pregnant women at Omdurman Maternity Hospital that was in concordance with the finding reported from Italy, 0.47\% (Barbi M et al. 1998), Sweden, 0.46\% (Ahlfors K et al. 1999) and US, 0.48\% (Murph JR et al. 1998).

The discrepancy in the reported results of congenital CMV infection between ELISA test and conventional PCR could be due to differences in the sensitivity and specificity of the methods. The ideal diagnostic test should be sufficiently sensitive to detect infection at an early stage before clinically significant disease has occurred; the test should also eliminate the false positive results. Detection of HCMV DNA is most likely to be useful in this way because it has high sensitivity and more specificity than serological methods (ELISA). Positive IgM ELISA and negative DNA results might be to due to the persistence of the IgM antibodies for a long time after infection in some apparently healthy individual, where virus load may be too low to be detected by PCR.

In conclusion, Cytomegalovirus showed low prevalence in infants with hydrocephalus, neural tube defect and microcephaly in Khartoum State. This study should pave the way for more research on various area of HCMV infection including different sources of virus, the association between HCMV acquisition and various risk factors such occupation, ethnicity, geographical location, hospitalization, antibiotic usage, surgery and disinfection. Also other causes of childhood congenital defects such as rubella virus should warrant further investigation.

\section{CONFLICT OF INTEREST}

The authors confirm that this article content has no conflict of interest.

\section{ACKNOWLEDGEMENTS}

We would like to thank the staff of Central Laboratory for help and encouragement.

\section{REFERENCES}

[1] Casteels A, Naessens A, Gordts F, De Catte L, Bougatef A, Foulon W. Neonatal screening for congenital cytomegalovirus infections. J Perinat Med 1999; 27(2): 116-21.

[http://dx.doi.org/10.1515/JPM.1999.015] [PMID: 10379501]

[2] Stagno S, Pass RF, Cloud G, et al. Primary cytomegalovirus infection in pregnancy. Incidence, transmission to fetus, and clinical outcome. JAMA 1986; 256(14): 1904-8.

[http://dx.doi.org/10.1001/jama.1986.03380140074025] [PMID: 3020264]

[3] Mussi-Pinhata MM, Yamamoto AY, Moura Brito RM, et al. Birth prevalence and natural history of congenital cytomegalovirus infection in a highly seroimmune population. Clin Infect Dis 2009; 49(4): 522-8. [http://dx.doi.org/10.1086/600882] [PMID: 19583520]

[4] Yamamoto AY, Mussi-Pinhata MM, Isaac MdeL, et al. Congenital cytomegalovirus infection as a cause of sensorineural hearing loss in a highly immune population. Pediatr Infect Dis J 2011; 30(12): 1043-6.

[http://dx.doi.org/10.1097/INF.0b013e31822d9640] [PMID: 21814153]

[5] Boppana SB, Rivera LB, Fowler KB, Mach M, Britt WJ. Intrauterine transmission of cytomegalovirus to infants of women with preconceptional immunity. N Engl J Med 2001; 344(18): 1366-71.

[http://dx.doi.org/10.1056/NEJM200105033441804] [PMID: 11333993] 
[6] Yamamoto AY, Mussi-Pinhata MM, Boppana SB, et al. Human cytomegalovirus reinfection is associated with intrauterine transmission in a highly cytomegalovirus-immune maternal population. Am J Obstet Gynecol 2010; 202(3): 297.e1-8.

[http://dx.doi.org/10.1016/j.ajog.2009.11.018]

[PMID: 20060091]

[7] Stagno S, Pass RF, Dworsky ME, et al. Congenital cytomegalovirus infection: The relative importance of primary and recurrent maternal infection. N Engl J Med 1982; 306(16): 945-9.

[http://dx.doi.org/10.1056/NEJM198204223061601] [PMID: 6278309]

[8] Wang C, Zhang X, Bialek S, Cannon MJ. Attribution of congenital cytomegalovirus infection to primary versus nonprimary maternal infection. Clin Infect Dis 2011; 52(2): e11-3. [http://dx.doi.org/10.1093/cid/ciq085] [PMID: 21288834]

[9] Drouet E, Michelson S, Denoyel G, Colimon R. Polymerase chain reaction detection of human cytomegalovirus in over 2000 blood specimens correlated with virus isolation and related to urinary virus excretion. J Virol Methods 1993; 45(3): 259-76.

[http://dx.doi.org/10.1016/0166-0934(93)90112-5] [PMID: 8106600]

[10] Mendez JC, Espy MJ, Smith TF, Wilson JA, Paya CV. Evaluation of PCR primers for early diagnosis of cytomegalovirus infection following liver transplantation. $\mathrm{J}$ Clin Microbiol 1998; 36(2): 526-30. [PMID: 9466770]
[11] Nahla KH, Ali YH, Enan KH. Studies on congenital infections in Sudan: Seroprevalence of cytomegalovirus. J Sci Tech 2011; 12(4): 82-90.

[12] Khairi SI, Intisar KS, Enan KH, Ishag MY, Baraa AM, Ali YH. Seroprevalence of cytomegalovirus infection among pregnant women at Omdurman Maternity Hospital. Sudan J Med Lab Diagn 2013; 4(4): 45-9.

[http://dx.doi.org/10.5897/JMLD2013.0075]

[13] Barbi M, Binda S, Primache V, Clerici D. Congenital cytomegalovirus infection in a northern Italian region. Eur $\mathrm{J}$ Epidemiol 1998; 14(8): 791-6.

[http://dx.doi.org/10.1023/A:1007554726449] [PMID: 9928874]

[14] Ahlfors K, Ivarsson SA, Harris S. Report on a long-term study of maternal and congenital cytomegalovirus infection in Sweden. Review of prospective studies available in the literature. Scand J Infect Dis 1999; 31(5): 443-57. [http://dx.doi.org/10.1080/00365549950163969] [PMID: 10576123]

[15] Murph JR, Souza IE, Dawson JD, et al. Epidemiology of congenital cytomegalovirus infection: maternal risk factors and molecular analysis of cytomegalovirus strains. Am J Epidemiol 1998; 147(10): 940-7.

[http://dx.doi.org/10.1093/oxfordjournals.aje.a009384] [PMID: 9596472]

Received: May 12, 2015

Revised: October 16, 2015

Accepted: October 20, 2015

(C) Ebrahim et al.; Licensee Bentham Open.

This is an open access article licensed under the terms of the (https://creativecommons.org/licenses/by/4.0/legalcode), which permits unrestricted, noncommercial use, distribution and reproduction in any medium, provided the work is properly cited. 